\title{
Efforts to Improve the Skills of Viewing Fables Using Fantasy Wayang Media in Class I SDN 2 Arjasari
}

\author{
Diana Dewi Nurhayati, Cece Rakhmat, Agus Ahmad Wakih
}

Universitas Perjuangan Tasikmalaya

dianadewinurhayati@gmail.com

\section{Article History}

accepted 05/11/2020

approved 10/11/2020

published 01/02/2021

\begin{abstract}
This research is motivated by low listening skills, especially in fable stories. This study aims to improve listening skills to fable stories using fantasy puppet media. This type of research uses PTK with the first cycle using fable story "Friendship of the Lion and the Rat", second cycle using the story of the fable "The Greedy Crocodile". The technique of collecting data was by seeing the class teacher learning without using fantasy puppet media and giving 10 PG questions. The results showed an increase in listening skills the first cycle the number of students who received a complete score was 4 students with a percentage of $57 \%$ completeness, in the second cycle the number of students who received a complete score was 7 students with a percentage of $100 \%$ completeness. It was concluded that the fantasy puppet media used in reading fable stories could improve students listening skills.
\end{abstract}

Keywords: fantasy puppet media, listening skills, fable story

\section{Abstrak}

Penelitian ini dilatar belakangi oleh rendahnya keterampilan menyimak khususnya dalam cerita fabel. Penelitian ini bertujuan untuk meningkatkan keterampilan menyimak cerita fabel menggunakan media wayang fantasi. Jenis penelitian ini menggunakan PTK dengan siklus I menggunakan cerita fabel "Persahabatan Singa dan Tikus", siklus II menggunakan cerita fabel "Buaya yang Serakah". Teknik pengumpulan data dengan cara melihat guru kelas melakukan pembelajaran tanpa menggunakan media wayang fantasi dan dilakukan pemberian 10 soal PG. Hasil penelitian menunjukkan peningkatan keterampilan menyimak pada siklus I jumlah yang mendapat nilai tuntas adalah 4 siswa dengan persentase ketuntasan $57 \%$, pada siklus II jumlah yang mendapat nilai tuntas adalah 7 siswa dengan persentase ketuntasan $100 \%$. Disimpulkan bahwa media wayang fantasi digunakan dalam membacakan cerita fabel dapat meningkatkan keterampilan menyimak siswa.

Kata kunci: media wayang fantasi, keterampilan menyimak, cerita fabel

Social, Humanities, and Education Studies (SHEs): Conference Series https://jurnal.uns.ac.id/shes 


\section{PENDAHULUAN}

Menurut Ambarani (2015: 2) bahasa dibagi menjadi empat macam bentuk yaitu: Menyimak, berbicara, membaca, dan menulis. Bahasa ada yang bersifat aktif reseptif (menerima pesan) yaitu menyimak dan membaca, serta bersifat aktif produktif (menyampaikan pesan) yaitu berbicara dan menulis. Menyimak merupakan suatu kegiatan mendengarkan (memperhatikan) baik-baik apa yang didengar untuk memperoleh informasi, memahami pesan yang terkandung dan dapat merespon bahan simakan yang didengar secara lisan. Berdasarkan permendiknas nomor 58 tahun 2009 menjelaskan bahwa anak usia 4 sampai 6 tahun sudah dapat menyimak perkataan orang lain (bahasa ibu atau bahasa lainnya). Dapat penulis simpulkan bahwa menyimak merupakan salah satu macam bahasa yang harus dikuasai siswa Sekolah Dasar (SD) karena dengan menyimak siswa akan memperoleh informasi dari apa yang siswa dengar.

Namun, pada saat ini keterampilan menyimak siswa dihadapkan dengan sejumah kendala seperti guru sulit mengarahkan siswa dalam memahami isi cerita fabel yang dibacakan karena siswa dengan pemahaman sendiri akan berimajinasi secara bebas. Beda halnya jika siswa menyimak cerita fabel menggunakan media, siswa akan dengan mudah memahami isi cerita serta imajinasi siswa dapat diarahkan.

Oleh sebab itu, penulis berinisiatif untuk melaksanakan pembelajaran dengan menggunakan media pembelajaran wayang fantasi dengan harapan dapat meningkatkan keterampilan menyimak cerita fabel. Pada penelitian ini menggunakan metode Penelitian Tindakan Kelas (PTK). Dengan demikian, rumusan masalah yang ditetapkan adalah Bagaimanakah perencanaan pembelajaran dalam upaya meningkatkan keterampilan menyimak cerita fabel menggunakan media wayang fantasi di kelas I SDN 2 Arjasari?, Bagaimanakah pelaksanaan pembelajaran menyimak cerita fabel menggunakan media wayang fantasi di kelas I SDN 2 Arjasari?, Adakah peningkatan hasil belajar siswa dalam keterampilan menyimak cerita fabel menggunakan media wayang fantasi di kelas I SDN 2 Arjasari?

\section{METODE}

Metode penelitian yang digunakan dalam penelitian ini adalah Penelitian Tindakan Kelas (Classroom Action Reasearch). Penelitian ini dilaksanakan dalam dua siklus. Menurut Arikunto (2008:16) mengemukakan dalam melaksanakan penelitian tindakan kelas (PTK) dibutuhkan empat tahapan sebagai berikut:

1. Perencanaan yang matang perlu dilakukan setelah kita mengetahui masalah dalam penelitian kita.

2. Perencanaan harus diwujudkan dengan adanya tindakan dari guru berupa solusi tindakan sebelumnya.

3. Selanjutnya diadakan pengamatan yang teliti terhadap proses pelaksanaan.

4. Setelah diamati, barulah guru dapat melakukan refleksi dan dapat menyimpulkan apa yang telah terjadi dalam kelasnya.

Adapun populasi dalam penelitian ini adalah kelas I di SDN 2 Arjasari Kecamatan Leuwisari Kabupaten Tasikmalaya. Sampel dalam penelitian ini adalah 7 siswa diambil dari satu kelas yakni kelas I. Terdiri dari 3 siswa laki-laki dan 4 siswa perempuan. Teknik penentuan dan penarikan sampel yang digunakan yaitu sampling jenuh karena semua anggota populasi digunakan sebagai sampel dalam penelitian. Dalam penelitian ini penulis menggunakan penelitian kuantitatif. Data kuantitatif yang digunakan yaitu nilai tes diperoleh dari nilai tes siswa yang berbentuk angka. Data berbentuk kuantitatif dianalisis dengan menggunakan analisis statistik deskriptif yaitu membandingkan antara nilai tes pada pra siklus, siklus I, dan siklus II. Data yang diperoleh dari hasik observasi berbentuk data kuantitatif dianalisis melalui analisis deskriptif kuantitatif.

Adapun teknik pengumpulan data yang digunakan berupa observasi dan tes. Observasi ini dilaksanakan saat proses belajar mengajar berlangsung untuk 
mengetahui karakteristik siswa yang sudah di bangun, sedangkan tes yang digunakan pada penelitian ini adalah tes tertulis berupa soal pilihan ganda (PG) yang dilakukan di akhir siklus.

\section{HASIL DAN PEMBAHASAN}

Penelitian Tindakan Kelas dilaksanakan di SDN 2 Arjasari. Hasil penelitian yang diuraikan berisi data mengenai proses kegiatan menyimak cerita fabel dengan media wayang fantasi. Berdasarkan data yang didapat dari hasil penelitian pra siklus dengan jumlah 7 siswa, hanya 1 siswa yang berhasil mencapai KKM dan 6 siswa belum mencapai KKM sehingga persentase ketuntasan yang diperoleh sebesar $14 \%$. Pengamatan selanjutnya dilakukan dengan pemberian soal pilihan ganda (PG) pada siklus I. Berdasarkan hasil pengamatan diperoleh penilaian hasil belajar siswa berikut:

\section{Tabel 1. Hasil Belajar Siswa Kelas I siklus I}

\begin{tabular}{|c|c|c|c|c|c|}
\hline No & Nama Siswa & $\mathrm{L} / \mathrm{P}$ & KKM & Nilai & Keterangan \\
\hline 1. & A1 & $\mathrm{L}$ & 69 & 60 & Belum Tuntas \\
\hline 2. & A2 & $P$ & 69 & 80 & Tuntas \\
\hline 3. & A3 & L & 69 & 80 & Tuntas \\
\hline 4. & A4 & $P$ & 69 & 80 & Tuntas \\
\hline 5. & A5 & $\mathrm{P}$ & 69 & 60 & Belum Tuntas \\
\hline 6. & A6 & $\mathrm{L}$ & 69 & 70 & Tuntas \\
\hline 7. & A7 & $P$ & 69 & 50 & Belum Tuntas \\
\hline \multicolumn{4}{|c|}{ Jumlah Nilai } & 390 & \\
\hline \multicolumn{4}{|c|}{ Nilai Rata-rata } & 68 & \\
\hline \multicolumn{4}{|c|}{ Jumlah Siswa yang Tuntas } & 4 & \\
\hline \multicolumn{4}{|c|}{ Jumlah Siswa yang Tidak Tuntas } & 3 & \\
\hline \multicolumn{4}{|c|}{ Persentase Ketuntasan Belajar } & $57 \%$ & \\
\hline
\end{tabular}

Berdasarkan data tersebut dapat diketahui bahwa dengan pembelajaran menggunakan media wayang fantasi untuk keterampilan menyimak di kelas 1 SDN 2 Arjasari pada siklus I terdapat peningkatan dibandingkan dengan pra siklus, terbukti dengan diperoleh nilai rata-rata siswa yaitu 68. Berikut ini adalah gambaran mengenai hasil keterampilan menyimak cerita fabel pada siklus I yaitu sebagai berikut:

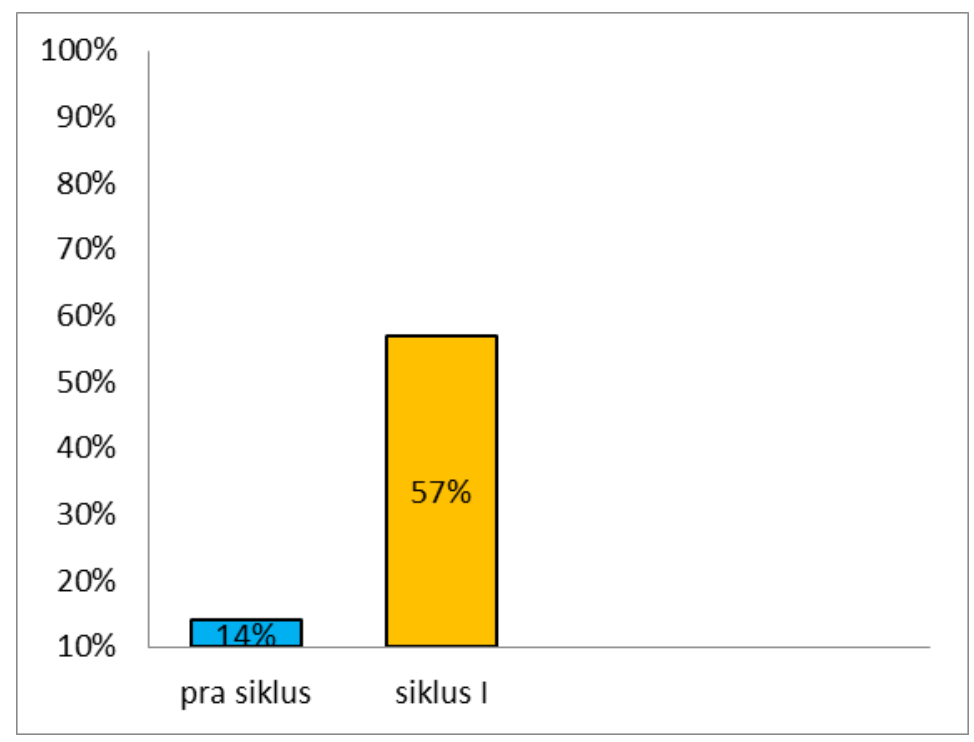

Gambar 1. Hasil Nilai Keterampilan Menyimak Siklus I 
Berdasarkan gambar 1 dapat disimpulkan bahwa keterampilan menyimak cerita fabel pada siklus I mengalami peningkatan. Sebagian siswa sudah mampu menyimak dan menjawab pertanyaan dengan baik namun masih perlu perbaikan karena banyak siswa yang nilainya belum mencapai KKM. Terdapat beberapa hal yang menyebabkan nilai siswa kurang maksimal yaitu selama proses pembelajaran berlangsung guru kurang optimal mempersiapkan media pembelajaran karena media wayang fantasi yang disiapkan hanya 2 tokoh serta guru kurang bisa mengefektifitaskan waktu karena ada beberapa siswa kurang memahami cerita sehingga guru harus mengulang kembali membacakan cerita. Langkah yang akan dilakukan yaitu memberikan cerita fabel yang dikemas menjadi menarik dengan tokoh wayang yang lebih banyak dan menyediakan panggung sebagai tempat wayang pentas.

Pada siklus II dilakukan pengamatan berdasarkan refleksi dari siklus I sehingga diperoleh hasil belajar siswa pada siklus II:

Tabel 2. Hasil Belajar Siswa Kelas I Siklus II

\begin{tabular}{|c|c|c|c|c|c|}
\hline No & Nama Siswa & $\mathrm{L} / \mathrm{P}$ & KKM & Nilai & Keterangan \\
\hline 1. & A1 & L & 69 & 80 & Tuntas \\
\hline 2. & $\mathrm{~A} 2$ & $\mathrm{P}$ & 69 & 90 & Tuntas \\
\hline 3. & A3 & L & 69 & 100 & Tuntas \\
\hline 4. & A4 & $\mathrm{P}$ & 69 & 100 & Tuntas \\
\hline 5. & A5 & $P$ & 69 & 80 & Tuntas \\
\hline 6. & A6 & L & 69 & 80 & Tuntas \\
\hline 7. & A7 & $P$ & 69 & 70 & Tuntas \\
\hline \multicolumn{4}{|c|}{ Jumlah Nilai } & 600 & \\
\hline \multicolumn{4}{|c|}{ Nilai Rata-rata } & 86 & \\
\hline \multicolumn{4}{|c|}{ Jumlah Siswa yang Tuntas } & 7 & \\
\hline \multicolumn{4}{|c|}{ Jumlah Siswa yang Tidak Tuntas } & 0 & \\
\hline \multicolumn{4}{|c|}{ Persentase Ketuntasan Belajar } & $100 \%$ & \\
\hline
\end{tabular}

Dari data tersebut diketahui bahwa dengan pembelajaran menggunakan media wayang fantasi untuk keterampilan menyimak di kelas I pada siklus II terdapat peningkatan dibandingkan dengan siklus $I$, terbukti dengan diperoleh nilai rata-rata siswa yaitu 86 dari KKM 69. Berikut adalah gambaran mengenai hasil keterampilan menyimak cerita fabel pada siklus II yaitu sebagai berikut: 


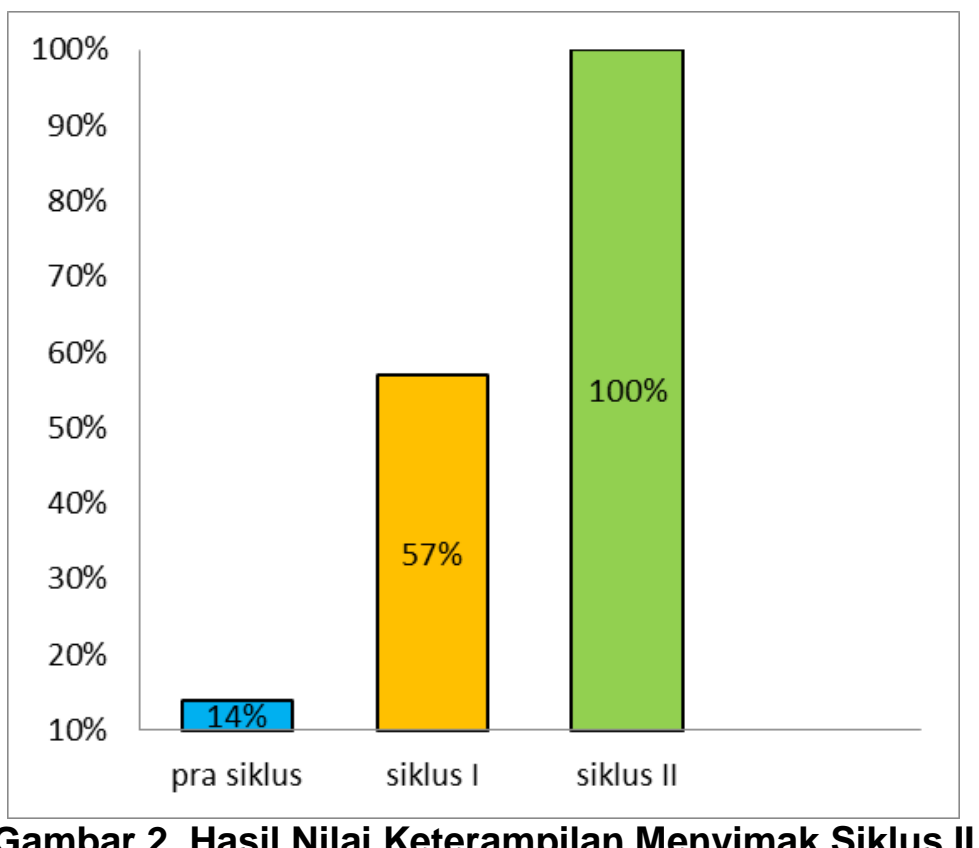

Berdasarkan gambar 2 dapat dilihat mengenai peningkatan keterampilan menyimak cerita fabel mulai dari pra siklus, siklus I, dan siklus II.Pada siklus II keterampilan menyimak siswa mengalami peningkatan terbukti pada siklus II yaitu dari 7 siswa, semua siswa sudah tuntas atau sudah mencapai KKM dengan persentase ketuntasan belajar siswa sebesar $100 \%$. Jadi penelitian yang dilakukan pada siklus II mengalami keberhasilan. Dan tidak perlu lagi melakukan penelitian ke siklus berikutnya.

Pelaksanaan dilakukan dengan dua siklus yaitu siklus I dan siklus II, namun sebelum siklus I dilaksanakan terlebih dahulu dilaksanakan pra siklus. Pra siklus dilakukan untuk mengetahui kondisi awal siswa dalam keterampilan menyimak sebelum dilakukan tindakan. Pada tahap perencanaan yaitu menentukan KI dan KD yang akan digunakan dalam pembelajaran, menyusun Rencana Pelaksanaan Pembelajaran (RPP), mempersiapkan ruang kelas di madrasah dengan menggelar karpet sebagai alas duduk karena tidak ada meja dan kursi sebagai pendukung kegiatan pembelajaran, mempersiapkan materi yang akan digunakan pada saat pembelajaran yaitu cerita fabel dengan judul "Persahabatan Singa dan Tikus" pada siklus I dan "Kisah Buaya yang Serakah" pada siklus II, mempersiapkan media pembelajaran wayang fantasi dengan 2 tokoh singa dan tikus pada siklus I dan media pembelajaran wayang fantasi dengan 4 tokoh buaya, bebek, kambing, dan gajah serta menyiapkan panggung wayang untuk pentas pada siklus II, mempersiapkan instrumen penelitian berupa LKPD dengan 10 soal pilihan ganda (PG), menetapkan kriteria keberhasilan dikatakan berhasil apabila nilai siswa mencapai kriteria ketuntasan minimal dengan nilai 69.

Tahap pelaksanaan yaitu melaksanakan kegiatan pembelajaran berdasarkan rencana pelaksanaan pembelajaran yang sudah disiapkan. Dengan menggunakan materi yang sama pada siklus I dan siklus II yaitu tema 5 subtema 1 pembelajaran 2 dengan kompetensi dasar 3.8 Merinci ungkapan penyampaian terima kasih, permintaan maaf, tolong, dan pemberian pujian, ajakan, pemberitahuan, perintah, dan petunjuk kepada orang lain dengan menggunakan bahasa yang santun secara lisan dan tulisan yang dapat dibantu dengan kosa kata bahasa daerah. 
Pengamatan yang dilakukan yaitu dengan pemberian tes berupa soal pilihan ganda (PG) sebanyak 10 soal yang disesuaikan dengan unsur-unsur intrinsik cerita fabel (tema, tokoh, latar, amanat) dan ungkapan penyampaian terimakasih, permintaan maaf, tolong, dan pemberian pujian. Dan pengamatan mengenai kegiatan pelaksanaan pembelajaran mengacu pada penggunaan media pembelajaran wayang fantasi dalam keterampilan menyimak. Berdasarkan hasil pengamatan yang telah dilakukan bahwa keterampilan menyimak cerita fabel siswa meningkat tiap siklusnya dan terbukti bahwa keterampilan menyimak cerita fabel siswa dapat meningkat dengan menggunakan media pembelajaran wayang fantasi. Hasil tersebut diketahui berdasarkan hasil dari penilaian soal tes yang telah dikerjakan oleh siswa.

Tabel 3. Hasil Belajar Siswa Klas I pra siklus, siklus I, dan siklus II

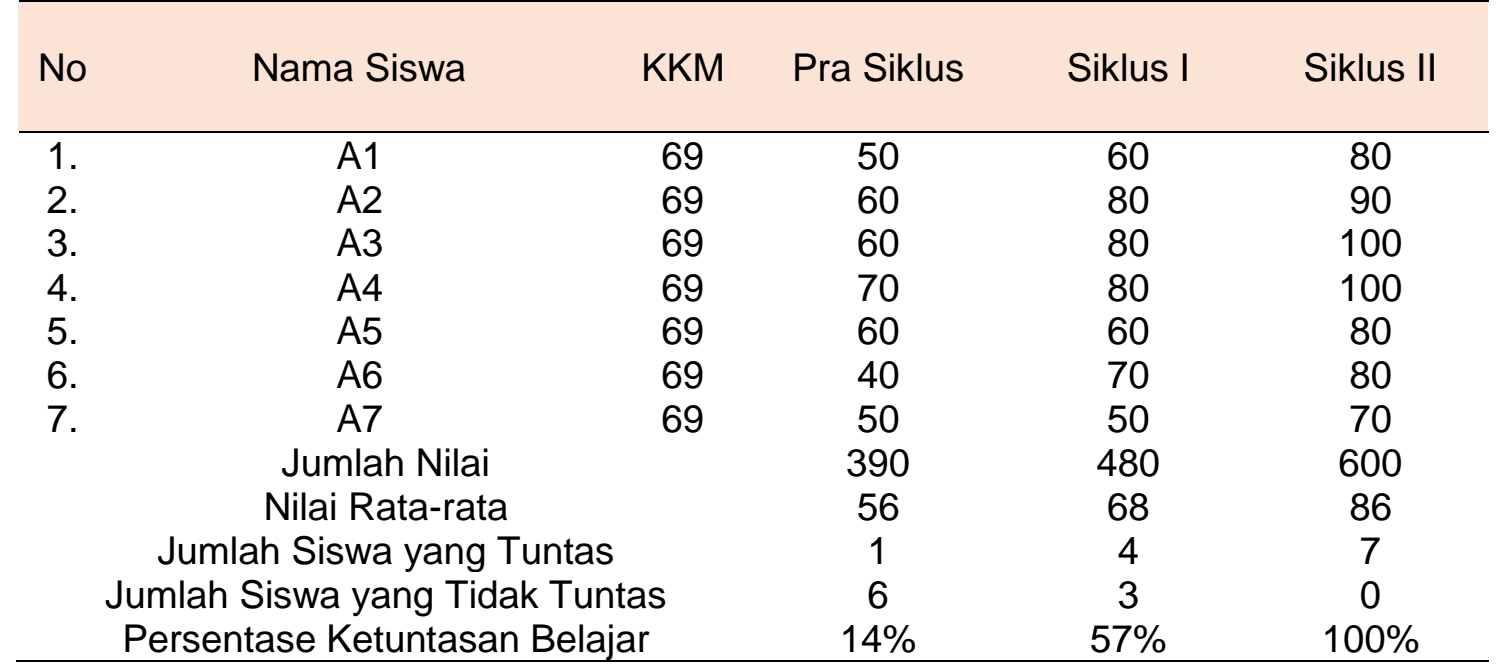

Berdasarkan tabel 3 dapat dilihat mengenai peningkatan hasil belajar muali dari pra siklus, siklus I, dan siklus II. Pada pra siklus hasil belajar masih sangat kurang karna masih rendahnya keterampilan menyimak cerita fabel sehingga dalam mengerjakan tes yang diberikan masih banyak siswa yang belum mencapai KKM yang diharapkan nilai rata-rata yang diperoleh yaitu 56, pada siklus I keterampilan menyimak cerita fabel mengalami peningkatan terbukti dengan hasil nilai yang meningkat jika dibandingkan dengan pra siklus sehingga nilai rata-rata menjadi 68, pada siklus II keterampilan menyimak cerita fabel mengalami peningkatan dan optimal terbukti dengan nilai rata-rata menjadi 86 dan pada siklus II nilai siswa sudah mencapai KKM yang diinginkan. Peningkatan tersebut terjadi setelah digunakannya media pembelajaran wayang fantasi. Jadi penelitian yang dilakukan pada siklus II mengalami keberhasilan. Hasil membuktikan bahwa keterampilan menyimak cerita fabel menggunakan media wayang fantasi dapat meningkatkan keterampilan menyimak siswa dan juga hasil perbaikan siklus I yang dilakukan pada siklus II yang membuat pembelajaran lebih optimal dan sesuai dengan yang diharapkan.

\section{SIMPULAN}

Berdasarkan hasil yang telah diuraikan, bahwa dengan menggunakan media pembelajaran wayang fantasi dalam membacakan cerita fabel dapat menigkatkan keterampilan menyimak, dan dapat disimpulkan sebagai berikut:

1. Perencanaan yang dilakukan dalam upaya meningkatkan keterampilan menyimakcerita fabel menggunakan media wayang fantasi meliputi pembuatan rencana pelaksanaan pembelajaran (RPP), LKPD, serta menyediakan media pembelajaran wayang fantasi untuk memudahkan siswa dalam menyimak cerita fabel. 
2. Pelaksanaan pembelajaran dengan menerapkan media wayang fantasi dapat meningkatkan keterampilan menyimak cerita fabel. Hal ini membuktikan bahwa dengan menerapkan media wayang fantasi siswa dapat menyimak dengan seksama.

3. Peningkatan keterampilan menyimak cerita fabel menggunakan media wayang fantasi dilakukan dua siklus yaitu siklus I dan siklus II. Hasil pengamatan keterampilan menyimak siswa, dari siklus I ke siklus II mengalami peningkatan. Peningkatan dapat dibuktikan melalui tes tulis berupa soal pilihan ganda (PG) sebanyak 10 soal serta dibuktikan dengan pemahaman siswa pada cerita fabel yang dibacakan guru meningkat. Pada setiap siklus terdapat peningkatan dengan persentase ketuntasan belajar pada pra siklus hanya 14\% dengan 1 siswa yang tuntas dan 6 siswa belum tuntas, pada siklus I persentase ketuntasan belajar menjadi $57 \%$ dengan jumlah siswa yang tuntas 4 dan siswa yang belum tuntas 3 sedangkan pada siklus II persentase ketuntasan belajar menjadi $100 \%$ yaitu dari 7 siswa, semua siswa sudah tuntas atau sudah mencapai KKM.

\section{DAFTAR PUSTAKA}

Ali, Kemas Mas'ud. (2016). Keterampilan Menyimak Memperngaruhi Kemampuan Siswa Memahami Materi Pendidikan Agama Islam. At-Ta'lim. 15 (1).

Ambarani, Pande Kadek, dkk. (2015). Penerapan Metode Bercerita Berbantuan Media Gambar Berseri untuk Meningkatkan Keterampilan Menyimak Anak. Jurnal PG PAUD Universitas Pendidikan Ganesha, 3 (1).

Iskandar, Denny. (2014). Pengembangan Model Pendekatan Integratif dalam Pembelajaran Menyimak sebagai Upaya Meningkatkan Daya Simak Mahasiswa di Jurusan Bahasa dan Sastra Indonesia FPBS UPI Bandung. Bandung.

Nurgiyantoro, Burhan. (2005). Sastra Anak. Yogyakarta: Gajah Mada University Press. Suharsimi Arikunto, dkk. (2008). Penelitian Tindakan Kelas. Jakarta: Bumi Aksara

Yatmi. (2010). Upaya Peningkatan Kemampuan Membaca Melalui Metode Bercerita dengan Wayang Fantasi di Kelas A RA Al-lkhlas Kecandran Sidomkti Kota Salatiga Tahun Plajaran 2009/2010. Skripsi. Sekolah Tinggi Agama Islam Negeri (STAIN) Salatiga. 